\title{
New Stability Indicating RP-UFLC Method for the Determination of Bumetanide - A Potent Diuretic
}

\section{Mukthinuthalapati Mathrusri Annapurna*, Rangisetty Spandana Yasaswini and Avuthu Sai Sheela \\ Department of Pharmaceutical Analysis and Quality Assurance GITAM Institute of Pharmacy, GITAM (Deemed to be University), Visakhapatnam, Andhra Pradesh, India.}

*Corresponding Author: Mukthinuthalapati Mathrusri Annapurna, Department of Pharmaceutical Analysis and Quality Assurance GITAM Institute of Pharmacy, GITAM (Deemed to be University), Visakhapatnam, Andhra Pradesh, India.

Received: June 19, 2019; Published: July 18, 2019

DOI: $10.31080 /$ ASPS.2019.03.0343

\begin{abstract}
Bumetanide is a potent loop diuretic. A new ultrafast liquid chromatographic method has been developed for the assay and stability studies of Bumetanide in tablets and validated. Shimadzu Model CBM-20A/20 Alite UFLC system (Shimadzu Co., Kyoto, Japan) equipped with SPD M20A prominence photodiode array detector with C18 column $(250 \mathrm{~mm} \times 4.60 \mathrm{~mm}$ i.d. $5 \mu \mathrm{m}$ particle size $)$ was used with a mobile phase composition acetic acid: acetonitrile: water (0.1: 80: $20 \mathrm{v} / \mathrm{v}$ ) and flow rate of $1.2 \mathrm{~mL} / \mathrm{min}$ (UV detection at $220 \mathrm{~nm}$ ). Bumetanide has shown linearity $0.1-100 \mu \mathrm{g} / \mathrm{mL}$ with linear regression equation $\mathrm{y}=70867 \mathrm{x}+3608(\mathrm{r} 2=0.9996)$. The LOQ was found to be $0.0964 \mu \mathrm{g} / \mathrm{mL}$ and the LOD was found to be $0.03091 \mu \mathrm{g} / \mathrm{mL}$. Bumetanide was subjected to forced degradation and the method was validated as per ICH guidelines.
\end{abstract}

Keywords: Bumetanide; RP-UFLC; Stability Indicating; Validation; ICH Guidelines

\section{Introduction}

Bumetanide, is a medication used to treat swelling and high blood pressure which include swelling as a result of heart failure, liver failure, or kidney problems. Bumetanide is a loop diuretic and works by decreasing the reabsorption of sodium by the kidneys [1]. Bumetanide (Figure 1) can lessen symptoms such as shortness of breath and swelling in your arms, legs, and abdomen. Bumetanide tablets are indicated for the treatment of edema associated with congestive heart failure, hepatic and renal disease, including the nephrotic syndrome. It is taken by mouth, or by injection into a vein or muscle and effects generally begin within an hour and lasts for about six hours. People with sulfa allergy are allergic to $\mathrm{Bu}$ metanide. Bumetanide was patented in 1968 and came into medical use in 1972 and it is available as a generic medication.<smiles>CCCCNc1cc(C(=O)O)cc(S(N)=O)c1Oc1ccccc1</smiles>

Figure 1: Chemical structure of Bumetanide

Bumetanide was determined in biological fluids like plasma, urine etc by HPLC [2,3] and with amperometric detection [4] and LC-MS [5] where as a very few methods were developed for its as- 
say in pharmaceuticals using HPLC [6,7], automated flow injection with fluorimetric detection [8], UPLC [9], HPTLC [10] and spectrophotometry [11]. In the present study the authors have developed a robust and economic stability indicating method for the quantification of Bumetanide in tablets. The method was validated as per ICH guidelines [12-13].

\section{Materials and Methods}

Instrumentation

Chromatographic separation was achieved by Shimadzu Model CBM-20A/20 Alite UFLC system (Shimadzu Co., Kyoto, Japan) equipped with SPD M20A prominence photodiode array detector on C18 column ( $250 \mathrm{~mm} \times 4.60 \mathrm{~mm}$ i.d. $5 \mu \mathrm{m}$ particle size) maintained at room temperature.

\section{Preparation of bumetanide drug solution}

Accurately weighed $25 \mathrm{mg}$ of Bumetanide was taken in a $25 \mathrm{~mL}$ volumetric flask and volume is made up to the mark with HPLC grade acetonitrile $(1000 \mu \mathrm{g} / \mathrm{mL})$ and dilutions were made with mobile phase and filtered through $0.45 \mu \mathrm{m}$ membrane filter prior to injection.

\section{Method validation}

Linearity

A series of (0.1-100 $\mu \mathrm{g} / \mathrm{mL})$ Bumetanide solutions were prepared from the stock solution with mobile phase and $20 \mu \mathrm{L}$ of each of these solutions were injected in to the UFLC system. The mean peak area of Bumetanide were calculated from the chromatograms and a calibration curve was drawn by taking the concentration of the Bumetanide solutions on the $\mathrm{x}$-axis and the corresponding mean peak area values on the $y$-axis.

\section{Precision, accuracy and robustness}

Intraday and inter-day precision were studied using three different concentrations of Bumetanide on the same day and on three consecutive days respectively and the \% RSD was calculated. The accuracy of the assay method was evaluated in triplicate at three concentration levels (50, 100 and 150\%), and the percentage recoveries were calculated. Standard addition and recovery experiments were conducted to determine the accuracy of the method for the quantification of Bumetanide in the drug product and the percentage recovery was calculated. The robustness of the method was assessed by exposing the drug solution to different analytical conditions purposely changing from the original optimized conditions. The effects so obtained were summarized to calculate the
\% RSD and has to be less than $2.0 \%$ specifying that the proposed method was robust.

\section{Forced degradation studies}

Forced degradation studies were performed to determine the ability of the drug to withstand its properties in the applied stress conditions. Bumetanide was exposed to different stress conditions such as acidic hydrolysis, basic hydrolysis and thermal treatment.

Acidic degradation was performed by treating the drug solution with $1 \mathrm{~mL}$ of $0.1 \mathrm{~N} \mathrm{HCl}$, heated at $80{ }^{\circ} \mathrm{C}$ for about 30 minutes on a water bath. The stressed sample is then cooled neutralized with $1 \mathrm{~mL} 0.1 \mathrm{~N}$ sodium hydroxide solution and the solution was made up to volume to the required concentration with the mobile phase. 20 $\mu \mathrm{l}$ of the solution was injected in to the UFLC system.

Alkaline degradation, was performed by treating the drug solution with $1 \mathrm{~mL} 0.1 \mathrm{~N} \mathrm{NaOH}$ heated at $80^{\circ} \mathrm{C}$ for 30 minutes on a water bath. The solution is then cooled and neutralized with $1 \mathrm{~mL} 0.1 \mathrm{~N}$ hydrochloric acid and diluted with mobile phase. $20 \mu \mathrm{l}$ of the solution was injected in to the UFLC system.

Thermal degradation was performed by heating the drug solution at $80^{\circ} \mathrm{C}$ for 30 minutes on a water bath. The solution is then cooled and diluted with mobile phase. $20 \mu \mathrm{l}$ of the solution was injected in to the UFLC system.

\section{Assay of bumetanide tablets}

Twenty tablets were procured, crushed and powdered. Powder equivalent to $25 \mathrm{mg}$ Bumetanide was extracted using the mobile phase in a $25 \mathrm{ml}$ volumetric flask. The solution was sonicated for half an hour and filtered through $0.45 \mathrm{~mm}$ membrane filter and 20 $\mu \mathrm{L}$ of this solution was injected in to the UFLC system and the peak area was noted at its retention time from the resultant chromatogram.

\section{Results and Discussion}

A new reverse phase ultrafast acting stability indicating method was developed for the quantification of Bumetanide in tablets. The previously reported liquid chromatographic methods were compared with the present method in Table 1.

A C18 column $(250 \mathrm{~mm} \times 4.60 \mathrm{~mm}$ i.d. $5 \mu \mathrm{m}$ particle size $)$ was selected with mobile phase composition acetic acid: acetonitrile: water (0.1: 80: $20 \mathrm{v} / \mathrm{v}$ ) and flow rate of $1.2 \mathrm{~mL} / \mathrm{min}$ (UV detection at $220 \mathrm{~nm}$ ) for the determination of Bumetanide by which a sharp 
peak was observed at $2.588 \mathrm{~min}$ (Run time $10 \mathrm{~min}$ ). The optimized

chromatographic conditions were shown in Table 2.

\begin{tabular}{|c|c|c|c|}
\hline Method/Mobile phase (v/v)/Reagent & $\lambda(\mathrm{nm})$ & Comment & Reference \\
\hline HPLC & $\begin{array}{l}\text { Exicitation (338) } \\
\text { Emission (433) }\end{array}$ & $\begin{array}{c}\text { Fluorimetric detection } \\
\text { (In plasma and urine) } \\
\text { (Acetophenone as Internal standard) }\end{array}$ & 2 \\
\hline $\begin{array}{l}\text { HPLC } \\
\text { Methanol: water: glacial acetic acid (66:34:1) }\end{array}$ & $\begin{array}{l}\text { Exicitation (228) } \\
\text { Emission (418) }\end{array}$ & $\begin{array}{l}\text { Fluorimetric detection } \\
\text { (In plasma and urine) }\end{array}$ & 3 \\
\hline $\begin{array}{l}\text { HPLC } \\
\text { Acetonitrile: } \mathrm{KH}_{2} \mathrm{PO}_{4} \text { buffer (pH 4.0) (50:50) }\end{array}$ & - & $\begin{array}{c}\text { Ampheometric detection } \\
\text { (in Urine) }\end{array}$ & 4 \\
\hline $\begin{array}{l}\text { LC-ESI-MS/MS } \\
\text { Methanol: 5mM Aq. ammonium trifluoroacetate }\end{array}$ & - & $\begin{array}{c}\text { Human plasma } \\
\text { (Tamsulosin as internal standard) }\end{array}$ & 5 \\
\hline $\begin{array}{l}\text { HPLC } \\
\text { Methanol: Water (70: 30) }\end{array}$ & 335 & $\begin{array}{l}\text { Low linearity } \\
1.0-10 \mu \mathrm{g} / \mathrm{ml}\end{array}$ & 6 \\
\hline $\begin{array}{l}\text { HPLC } \\
\text { Phosphate buffer (pH=7.8): Acetonitrile }(70: 30)\end{array}$ & 216 & $\begin{array}{l}\text { Low linearity } \\
0.6-1.6 \mu \mathrm{g} / \mathrm{ml}\end{array}$ & 7 \\
\hline $\begin{array}{l}\text { HPLC } \\
\text { Alkaline medium }\end{array}$ & $\begin{array}{l}\text { Exicitation (314) } \\
\text { Emission (370) }\end{array}$ & Fluorimetric detection & 8 \\
\hline $\begin{array}{l}\text { UPLC } \\
\text { Water: Acetonitrile (30: } 70)\end{array}$ & 254 & PDA & 9 \\
\hline $\begin{array}{l}\text { HPTLC } \\
\text { Toluene: Ethyl acetate: Formic acid } \\
(7: 3.5: 0.5)\end{array}$ & 335 & $100-800 \mathrm{ng} / \mathrm{spot}$ & 10 \\
\hline $\begin{array}{l}\text { Spectrophotometry } \\
\text { Borate buffer (pH 9.0) } \\
\text { Phosphate buffer (pH 7.0) }\end{array}$ & 252 & $\begin{array}{l}\text { Low linearity } \\
5.0-75 \mu \mathrm{g} / \mathrm{ml}\end{array}$ & 11 \\
\hline $\begin{array}{l}\text { UFLC } \\
\text { Acetonitrile: Water: Glacial acetic acid (80: 20: 0.1) }\end{array}$ & 220 & $\begin{array}{l}\text { High linearity } \\
0.1-100 \mu \mathrm{g} / \mathrm{ml}\end{array}$ & $\begin{array}{l}\text { Present } \\
\text { method }\end{array}$ \\
\hline
\end{tabular}

Table 1: Review of previously published methods with the present method.

\begin{tabular}{|c|c|}
\hline Parameter & $\begin{array}{l}\text { Optimized chromatographic } \\
\text { conditions }\end{array}$ \\
\hline Mobile Phase & $\begin{array}{c}\text { Acetonitrile: Water: Glacial acetic acid } \\
\text { (80: 20:0.1) }\end{array}$ \\
\hline Stationary Phase & $\begin{array}{l}\text { C18 Phenomenex column }(250 \mathrm{~mm} \times \\
4.60 \mathrm{~mm} \text { i.d. } 5 \mu \mathrm{m} \text { particle size })\end{array}$ \\
\hline Flow Rate & $1.2 \mathrm{~mL} / \mathrm{min}$ \\
\hline Detection wavelength & $220 \mathrm{~nm}$ \\
\hline Column temp. & $\left(25^{\circ} \pm 2^{\circ} \mathrm{C}\right)$ \\
\hline Injection Volume & $20 \mu \mathrm{L}$ \\
\hline Detector & $\begin{array}{l}\text { SPD M20A prominence photodiode } \\
\text { array detector }\end{array}$ \\
\hline Elution & Isocratic mode \\
\hline Total Run Time & 10 mins \\
\hline Retention time & $2.588 \mathrm{mins}$ \\
\hline
\end{tabular}

Linearity

Bumetanide has shown linearity over the concentration range $0.1-100 \mu \mathrm{g} / \mathrm{mL}$ (Table 3) (\% RSD 0.0017-0.9467) with linear regression equation $y=70867 x+3608\left(r^{2}=0.9996\right)$ (Figure 2$)$. The LOQ was found to be $0.0964 \mu \mathrm{g} / \mathrm{mL}$ and the LOD was found to be $0.03091 \mu \mathrm{g} / \mathrm{mL}$. The system suitability parameters for the $\mathrm{Bu}-$ metanide has shown that the tailing factor was less than 2 (or $<1.5$ 2.0) and the theoretical plates were more than 2000 .

\section{Precision, accuracy and robustness}

Intraday and inter-day precision were studied at three different concentration levels of Bumetanide on the same day and on three consecutive days respectively and the \% RSD was found to be 0.0087-0.1002 (Intraday) (Table 4) and 0.0069-0.0342 (Inter day) (Table 5) respectively $(<2.0)$ demonstrating that the method is precise. The accuracy of the method was proved by the standard addi-

Table 2: Optimized chromatographic conditions. 
tion method and the recovery values were $0.24-0.52(<2.0)$ with a recovery of $99.53-99.68 \%$ (Table 6 ). The robustness of the assay method was established by introducing small changes in the chromatographic conditions which include detection wavelength $(218$ and $222 \mathrm{~nm}$ ), percentage of acetonitrile in the mobile phase $(78$ and $82 \%)$ and flow rate $( \pm 0.1 \mathrm{ml} / \mathrm{min})$. Robustness of the method was studied using $10 \mu \mathrm{g} / \mathrm{mL}$ of Bumetanide (Table 7) and the $\%$ RSD was found to be 0.109-0.946 $(<2.0)$.

\begin{tabular}{|l|c|c|}
\hline Conc. $(\boldsymbol{\mu g} / \mathbf{m L})$ & *Mean peak area & \% RSD \\
\hline 0.1 & 7224 & 0.3105 \\
\hline 0.5 & 3612 & 0.9467 \\
\hline 1 & 72246 & 0.0644 \\
\hline 5 & 361230 & 0.1064 \\
\hline 10 & 705788 & 0.0419 \\
\hline 20 & 1453843 & 0.0088 \\
\hline 50 & 3546132 & 0.1003 \\
\hline 80 & 5779680 & 0.0017 \\
\hline 100 & 6999440 & 0.0038 \\
\hline
\end{tabular}

Table 3: Linearity of Bumetanide. *Mean of three replicates.

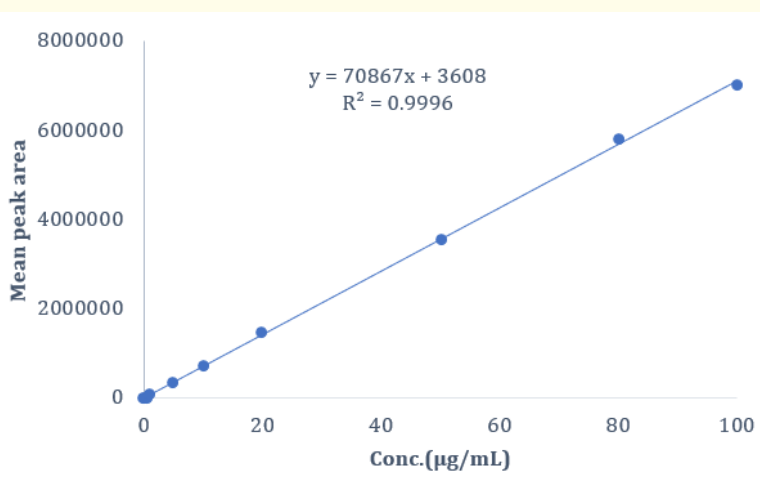

Figure 2: Calibration curve of Bumetanide.

\begin{tabular}{|c|c|c|}
\hline \multirow{2}{*}{$\begin{array}{l}\text { Conc. } \\
(\mu \mathrm{g} / \mathrm{mL})\end{array}$} & \multirow{2}{*}{$\begin{array}{c}* \text { Mean } \\
\text { peak area }\end{array}$} & Statistical Analysis \\
\hline & & $*$ Mean \pm SD (\% RSD) \\
\hline 10 & 705788 & \multirow{3}{*}{$705569 \pm 295.0497(0.0418)$} \\
\hline 10 & 705687 & \\
\hline 10 & 705234 & \\
\hline 20 & 1453843 & \multirow{3}{*}{$1453812 \pm 127.911(0.0087)$} \\
\hline 20 & 1453671 & \\
\hline 20 & 1453921 & \\
\hline 50 & 3546132 & \multirow{3}{*}{$3546519 \pm 355.590(0.1002)$} \\
\hline 50 & 3546595 & \\
\hline 50 & 3546831 & \\
\hline
\end{tabular}

Table 4: Intraday precision study of Bumetanide.

*Mean of three replicates

\begin{tabular}{|l|c|c|c|c|}
\hline \multirow{2}{*}{$\begin{array}{l}\text { Conc. } \\
(\boldsymbol{\mu} \mathbf{\mu g} / \\
\mathbf{m L})\end{array}$} & \multicolumn{3}{|c|}{ *Mean peak area } & \multirow{2}{*}{ *Mean $\mathbf{\text { SD }}$ (\% RSD) } \\
\cline { 2 - 5 } $\mathbf{1 0}$ & 705701 & 705758 & 707598 & $\begin{array}{c}70572 \pm 48.746 \\
(0.0069)\end{array}$ \\
\hline 20 & 1453985 & 1453521 & 1458970 & $\begin{array}{c}1453825 \pm 1090.369 \\
(0.075)\end{array}$ \\
\hline 50 & 3546254 & 3546625 & 3548521 & $\begin{array}{c}3547133 \pm 1215.987 \\
(0.0342)\end{array}$ \\
\hline
\end{tabular}

Table 5: Inter day precision study of Bumetanide.

${ }^{*}$ Mean of three replicates

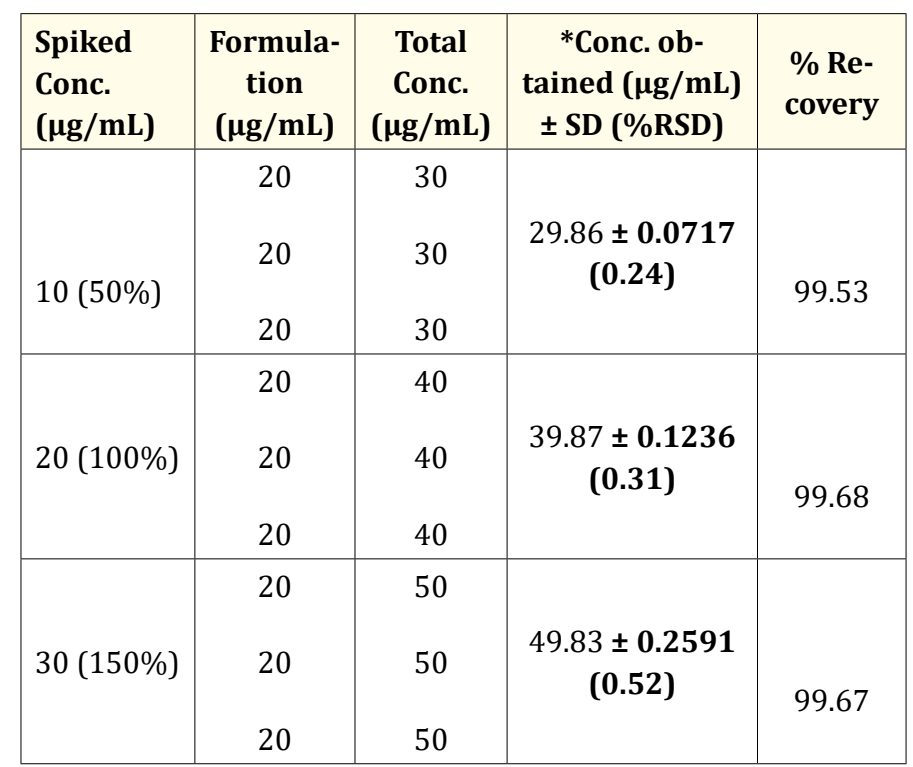

Table 6: Accuracy study of Bumetanide.

*Mean of three replicates

\begin{tabular}{|c|c|c|c|}
\hline Parameter & Condition & $\begin{array}{l}\text { *Mean } \\
\text { peak } \\
\text { area }\end{array}$ & $\begin{array}{c}* \text { Mean peak area } \\
\quad \text { I SD (RSD) }\end{array}$ \\
\hline \multirow{3}{*}{$\begin{array}{l}\text { Flow rate }( \pm \\
0.1 \mathrm{ml} / \mathrm{min})\end{array}$} & 1.1 & 714236 & \multirow{3}{*}{$\begin{array}{c}707015 \pm 6692.39 \\
(0.946)\end{array}$} \\
\hline & 1.2 & 705788 & \\
\hline & 1.3 & 701021 & \\
\hline \multirow{3}{*}{$\begin{array}{l}\text { Detection wave- } \\
\text { length }( \pm 2 \mathrm{~nm})\end{array}$} & 218 & 706924 & \multirow{3}{*}{$\begin{array}{c}706960 \pm 1190.916 \\
(0.168)\end{array}$} \\
\hline & 220 & 705788 & \\
\hline & 222 & 708169 & \\
\hline \multirow{3}{*}{$\begin{array}{l}\text { Mobile phase } \\
\text { composition } \\
\text { Acetic acid: Ace- } \\
\text { tonitrile: Water }\end{array}$} & $0.1: 72: 28$ & 706239 & \multirow{3}{*}{$\begin{array}{c}706442 \pm 774.0278 \\
(0.109)\end{array}$} \\
\hline & $0.1: 80: 20$ & 705788 & \\
\hline & $0.1: 78: 22$ & 707296 & \\
\hline
\end{tabular}

Table 7: Robustness study of Bumetanide *Mean of three replicates 


\section{Forced degradation studies}

Bumetanide was eluted at 2.588 min. Bumetanide has undergone acidic hydrolysis (6.46\%), thermal degradation $(1.71 \%)$ and alkaline hydrolysis $(0.74 \%)$ which is less than $10 \%$ indicating that the Bumetanide is more resistant towards all forced degradation conditions applied and only during alkaline hydrolysis an extra peak was observed at $2.289 \mathrm{~min}$ along with the drug peak at 2.603 min. The system suitability parameters were well in the acceptance criteria (Table 8). The individual chromatograms observed during the forced degradation studies were shown in Figure 3.

\begin{tabular}{|l|c|c|c|c|c|}
\hline Stress condition & Rt (min) & \% Recovery* & $\begin{array}{c}\text { \% Drug } \\
\text { degradation }\end{array}$ & $\begin{array}{c}\text { Theoretical } \\
\text { Plates (>2000) }\end{array}$ & $\begin{array}{c}\text { Tailing factor } \\
\text { (<1.5) }\end{array}$ \\
\hline Standard drug & 2.594 & 100 & ---- & 8876.430 & 1.430 \\
\hline $\begin{array}{l}\text { Acidic degradation } \\
0.1 \mathrm{~N} \mathrm{HCl} / 80^{\circ} \mathrm{C} / 30 \mathrm{~min}\end{array}$ & 2.607 & 93.54 & 6.46 & 7761.454 & 1.444 \\
\hline $\begin{array}{l}\text { Alkaline degradation } \\
0.1 \mathrm{~N} \mathrm{NaOH} / 80^{\circ} \mathrm{C} / 30 \mathrm{~min}\end{array}$ & 2.603 & 99.26 & 0.74 & 7456.420 & 1.427 \\
\hline $\begin{array}{l}\text { Thermal degradation } \\
80^{\circ} \mathrm{C} / 30 \text { min }\end{array}$ & 2.599 & 98.29 & 1.71 & 8763.680 & 1.412 \\
\hline
\end{tabular}

Table 8: Stress degradation studies of Bumetanide.

*Mean of three replicates
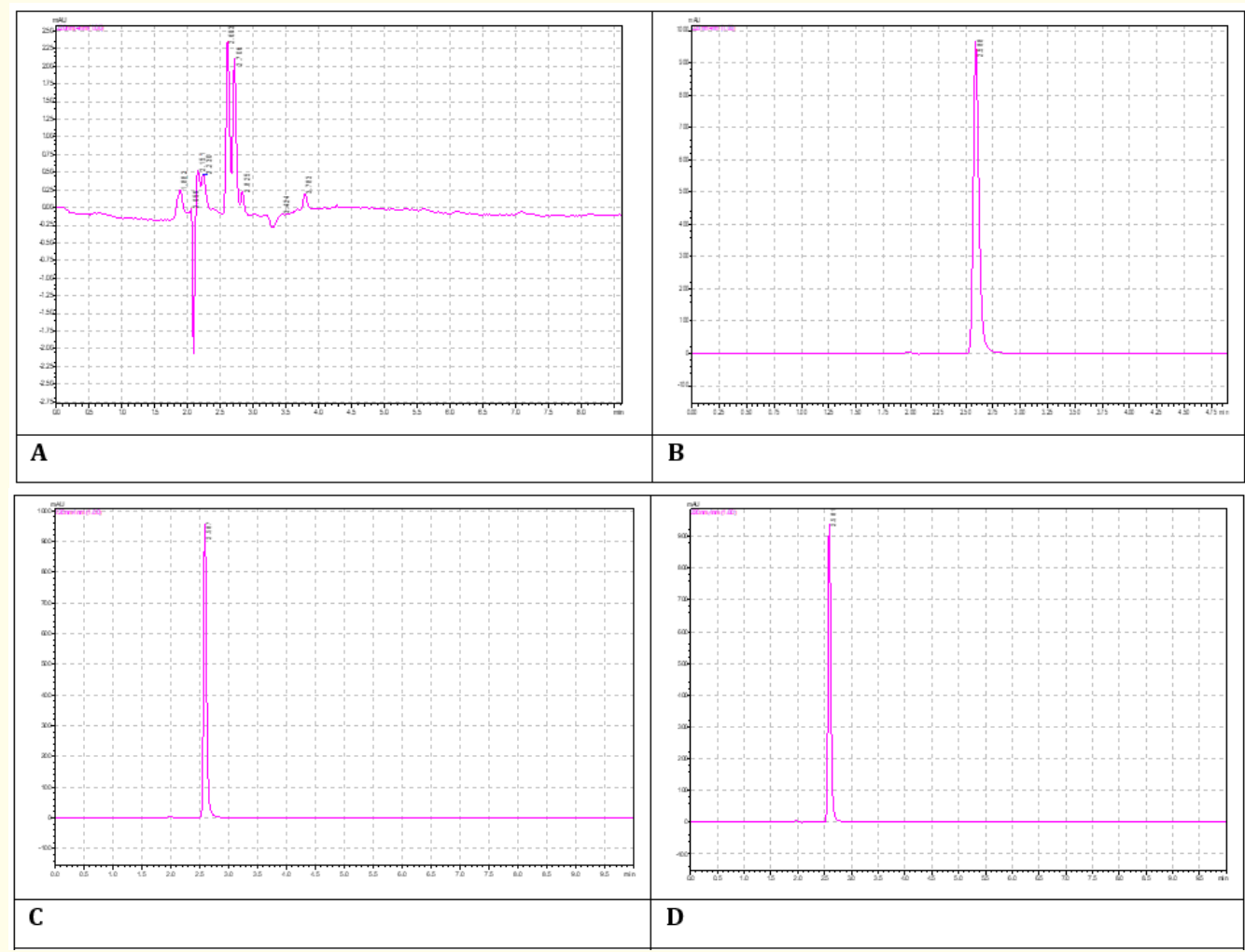


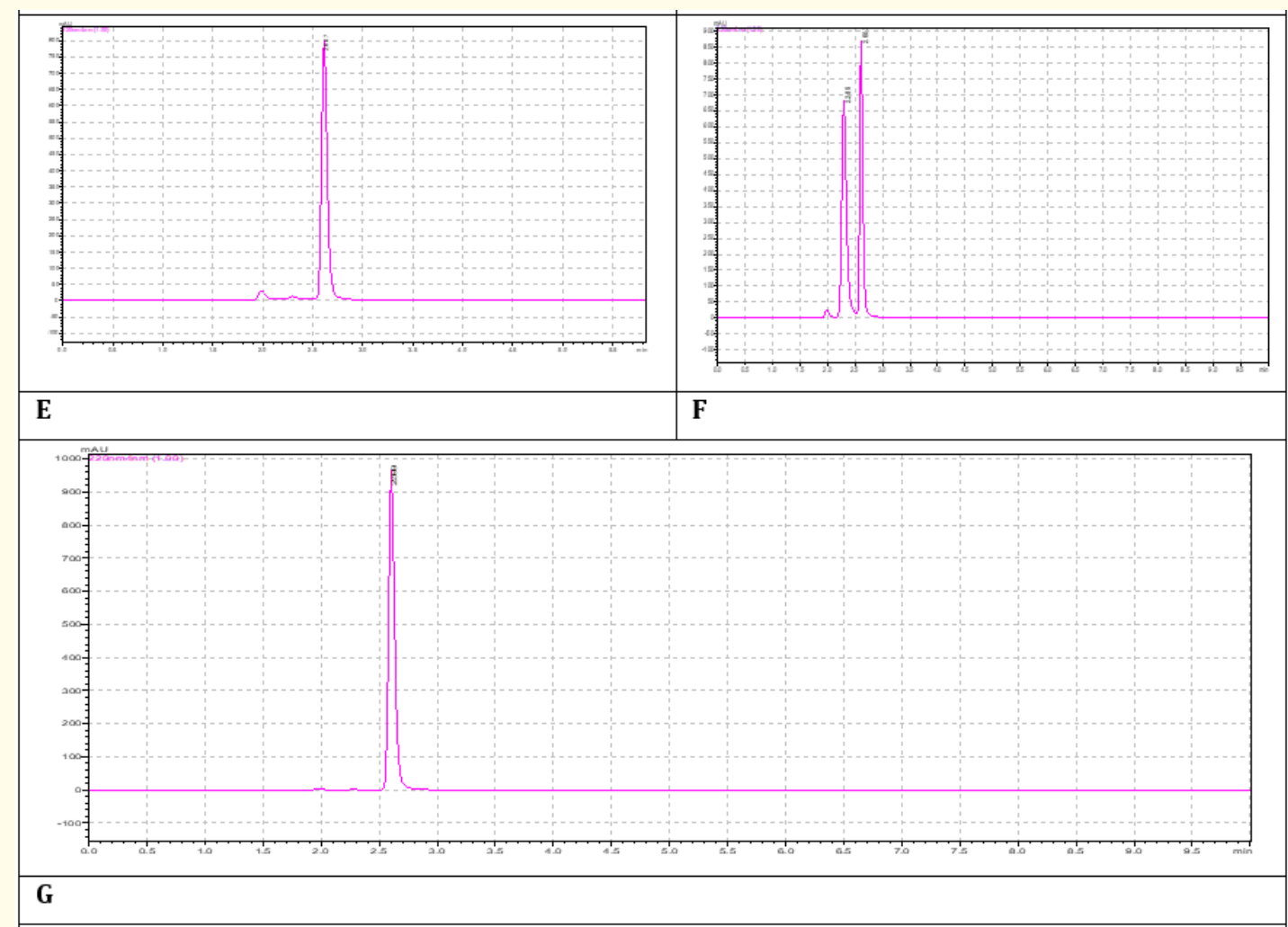

Figure 3: Typical chromatograms of A) Mobile phase B) Bumetanide API (50 $\mu \mathrm{g} / \mathrm{mL})$ C) Bumex (Label claim: $1 \mathrm{mg})(50 \mu \mathrm{g} / \mathrm{mL})$ D) Burinex (Label claim: $2 \mathrm{mg}$ ) (50 $\mu \mathrm{g} / \mathrm{mL})$ E) Acidic degradation F) Alkaline degradation and G) Thermal degradation.

\section{Assay of bumetanide tablets}

Assay was performed by using two different brands of $\mathrm{Bu}-$ metanide tablets consisting of $0.5,1$ and $2 \mathrm{mg}$ API and found that the amount of Bumetanide was found to be 99.60-99.80 (Table 9) and there is no interference of excipients.

\begin{tabular}{|l|c|c|c|c|c|}
\hline S. No. & Brand name & $\begin{array}{c}\text { Label claim } \\
\text { (mg) }\end{array}$ & $\begin{array}{c}\text { Observed } \\
\text { amount (mg) }\end{array}$ & \% Recovery* & Manufacturer (India) \\
\hline I & Bumex & 1 & 0.998 & 99.80 & Validus pharmaceuticals LLC \\
\hline II & Burinex & 2 & 1.993 & 99.65 & Leo pharma \\
\hline III & Bumex & 0.5 & 0.498 & 99.60 & Genentech, Inc \\
\hline
\end{tabular}

Table 9: Assay of Bumetanide tablets.

*Mean of three replicates 


\section{Conclusion}

The RP-UFLC techniques were validated as per ICH guidelines and found to be simple, economical and robust for the quantification of Bumetanide tablets.

\section{Acknowledgement}

The authors are grateful to M/s GITAM (Deemed to be University), Visakhapatnam for providing the research facilities and Genentech, Inc (India) for supplying gift samples of Bumetanide. The authors have no conflict of interest.

\section{Bibliography}

1. Feit PW. "Aminobenzoic acid diuretics. 2. 4-Substituted-3-amino-5-sulfamoyl benzoic acid derivatives". Journal of Medicinal Chemistry 14.5 (1971): 432-439.

2. Smith DE. "High-performance liquid chromatographic assay for Bumetanide in plasma and urine". Journal of Pharmaceutical Sciences 71.5 (1982): 520-523.

3. Wells TG., et al. "Measurement of Bumetanide in plasma and urine by High-performance liquid chromatography and application to Bumetanide disposition". Journal of Chromatography 570.1 (1991): 235-242.

4. Legorburu MJ., et al. "Quantitative determination of the loop diuretic Bumetanide in urine and pharmaceuticals by highperformance liquid chromatography with amperometric detection". Journal of Chromatographic Science 39 (2001): 425430.

5. Dinesh SP., et al. "Application of a rapid and sensitive liquid chromatography-tandem mass spectrometry method for determination of Bumetanide in human plasma for a bioequivalence study". Journal of Pharmaceutical and Biomedical Analysis 66 (2012): 365-370.

6. Rao JR., et al. "Stability indicating RP- HPLC method for Bumetanide in bulk drug and tablet formulation". Asian Journal of Research Chemistry 2.3 (2009): 266-269.

7. HUANG Qin., et al. "HPLC determination of the dissolution of Bumetanide tablets". Chinese Journal of Pharmaceutical Analysis 27.8 (2007): 1285-1287.

8. Solich P., et al. "Automated flow injection fluorimetric determination and dissolution studies of Bumetanide in pharmaceuticals". Analytica Chimica Acta 438.1-2 (2001): 131-136.
9. Chaitanya B., et al. "Method development, validation and stability studies for determination of Bumetanide in bulk and pharmaceutical dosage form by RP-UPLC". International journal of pharmacy and pharmaceutical sciences 10.3 (2018): 3542.

10. Mohan Kumar., et al. "Development and validation of a stability-indicating HPTLC method for analysis of Bumetanide in the bulk drug and tablet dosage form". Research Journal of Pharmacy and Technology 3.1 (2010): 239-243.

11. Chaitanya B., et al. "Method development and validation of Bumetanide by UV spectrophotometric method in bulk and pharmaceutical dosage form". European Journal of Biomedical and Pharmaceutical Sciences 5.3 (2018): 443-450.

12. ICH Validation of analytical procedures: Text and methodology Q2 (R1), International Conference on Harmonization (2005).

13. ICH Stability Testing of New Drug Substances and Products Q1A (R2), International Conference on Harmonization (2003).

\section{Volume 3 Issue 8 August 2019 \\ (C) All rights are reserved by Mukthinuthalapati Mathrusri Annapurna., et al.}

Citation: Mukthinuthalapati Mathrusri Annapurna., et al. "New Stability Indicating RP-UFLC Method for the Determination of Bumetanide - A Potent Diuretic". Acta Scientific Pharmaceutical Sciences 3.8 (2019): 84-90. 